\title{
Teaching Comparative Law, Pragmatically (Not Practically)
}

\author{
Special Issue on Pragmatism and Legal Education \\ Sanne Taekema \& Thomas Riesthuis (eds.)
}

Alexandra Mercescu*

\section{Summary}

Comparative legal studies, that is the theorizing about legal comparisons or the actual practice of contrasting two or more legal cultures, can be a rich source of epistemological insights for law in general. In particular, it has been shown to act as a tool of critical thinking. However, for students to actually grasp the critical potential of comparative law, more than just theoretical knowledge needs to be transmitted. It is crucial, this article will argue, to nurture a specific philosophical attitude, to be drawn along the lines of pragmatism, towards law and knowledge in general, with teaching playing an important role in bringing about this attitude. While the teaching of comparative law was discussed in sufficient detail in the past, it currently attracts less attention from academics in a context in which interest in the theory and practice of comparative law does not cease to grow. This investigation will discuss a series of pedagogical practices, meant to facilitate the educational mission of comparative legal instructors. These will range from the choice of subjects to be examined and materials to be read to the type of tasks to be assigned to students in their confrontation with legal alterity. The teaching of comparative law was much debated in the 1950s (Dainow 1951; Graveson 1950; Sereni 1951; Schlesinger 1954; Harding and Cueto-Rua 1955; Mueller 1958; Mayda 1959) and then, again, in the 1970s (Hazard 1971; Winterton 1975). Although the field generally called 'comparative law' has known many theoretical developments since the second half of the 20th century (for an inventory of the major developments, see Legrand and Munday 2003), the way in which comparative law is being taught has been given little attention (see, however, Waxman 2001; Ireland-Piper 2019; Varga 2020a). Or the revision of a discipline's epistemological foundation calls for a reimagination of the manner in which one

* Alexandra Mercescu, Ph.D is lecturer at the Department of Public Law, University of Timisoara, Romania.

In English as in French, Professor Pierre Legrand is always an 'enchanter'. For the views that I express here on the teaching of comparative law I am therefore indebted not only to his writings but also, considerably, to his invaluable pedagogical skills. 
goes about its teaching, especially so in a context in which higher education seems to be reinventing itself as well.

As a newcomer in the curriculum of many law faculties, comparative law has never been very rigid in its pedagogical manifestation, allowing from the very beginning for much more flexibility than traditional subject matters whose legacy often constrained the teacher to the point of depriving him or her of any innovative intervention in the design of their course. Indeed, at least in the civil-law world, it is often the case that one 'inherits' a course from one's predecessor, and while the receiver does enjoy a certain margin of discretion in respect of his or her teaching plans, he or she is certainly not expected to deviate significantly from their mentor's framework. All disciplines have disciplining effects (otherwise they would simply not be disciplines), but law is among the most disciplining of them all (for an account of the 'discipline' of law in this constraining sense, see Schlag 1998; Mercescu 2018). As such, comparative law found itself in a rather peculiar situation: a novel field of inquiry, and, moreover, one not characterized by a body of positive laws, entering the sea of (pedagogical) legal canons. This article will briefly summarize the concerns that ensued in the past in relation to comparative law's possible pedagogical configurations (Part I) and then offer a perspective on what comparative law should look like today, pedagogically speaking, as a response to its (yet to come) epistemic reshuffling. At various points, I will emphasize in what sense pragmatist thinking offers support for the philosophy of comparative education that I am advocating here. Importantly, I will emphasize that such a pragmatist approach should not be understood as encouraging a practical orientation in either the research or the teaching of comparative law (Part II). I see this contribution both as a research exercise imposed by changing times (every discipline needs from time to time to reflect on its pedagogical achievements) and as an ethical endeavour (every professor should take the time to consider how their knowledge is transmitted to students and how this has an impact on the very message one conveys). Part III concludes by rehearsing the importance of comparative law as a pedagogical practice to be engaged with pragmatically (not practically).

\section{Teaching Comparative Law in the Past}

As early as 1950, well-reputed comparatists such as Rudolf Schlesinger became aware of the stakes of pedagogy when it came to making comparative law - at the time a new area of legal investigation - into an appealing field of study. He stated the following:

The merchandise offered is of the highest quality. There are many who would derive enjoyment and profit from using that merchandise, but none will buy. The explanation, I submit, lies in a complete failure of salesmanship, or, if we leave the parable and return to our subject - in poor teaching. (Schlesinger 1954, 493) 
It is not surprising that pedagogy retained the interest of comparatists writing at the time, all the more so that many of them already noted the 'boundless' character of the discipline (Sereni 1951, 771). 'How was one to teach a subject that is effectively limitless, having no obvious borders like the more traditional subjects?' was the question that emerged as soon as comparative law made a place for itself in the curriculum of many law faculties. One author remarked that American professors could agree on the desirability of teaching comparative law, but this did not prevent their techniques of instruction '[from varying] in detail' (Graveson 1950, 32). While in-depth reflection on the apprehension of foreign law was lacking, it is possible to identify from the several writings a couple of main directions. The aftermath of World War II brought about a universalizing spirit that infiltrated legal discourse and became key to comparative law's subsequent epistemic (and pedagogical) agenda. Expressing nostalgia about the supposedly lost legal paradise of a uniform European law (to be located in the medieval ius commune), Schlesinger conceived of comparison as the tool apt, alongside international law, to identify the 'general principles of law accepted by civilized nations' and thus to offer lawyers a common vocabulary. He reminded us that

[n]ot many centuries ago, every lawyer had the linguistic and terminological ability to exchange thoughts with every one of his brethren within the orbit of Western civilization. The decline of classical education, and the advent of national codes and other forms of legal sectionalism, destroyed the cosmopolitan culture of our profession. (Schlesinger 1954, 501)

With this end in view, he emphasized that in their selection of working materials, teachers of comparative law should focus on choosing 'illustrative subjects and types of materials' dealing with 'problems which are likely to come up in the private or governmental work of lawyers practicing in the students' country' (ibid, 501). Other authors did not explicitly reject the aim of uniformization but expressed doubts about whether such a difficult subject can be usefully handled by students during the course of their classes (Sereni 1951, 775). Not all comparatists adhered to the similarity thesis. For instance, Graveson argued that ' $\mathrm{t}] \mathrm{he}$ choice of subject or branch of law should, it is considered, be based primarily on the contrasts which it affords with English or American law, not on its similarity to those systems' $(1950,35)$. In any case, whether comparatists were to get inspiration from similar or less similar systems, all authors agreed that the principal mission of comparative law lay in its practical contribution, where 'practical' generally meant the acquisition of foreign law knowledge for the purpose of practice (Graveson 1950), the identification of the better system for the purpose of reform (Mueller 1958) or the understanding of one's own system primarily for the purpose of knowledge but ultimately with a view to providing 'direct assistance to the practicing attorney' (Sereni 1951, 778).

In anticipation of possible critiques from his European colleagues as regards this practical agenda, Schlesinger retorted by asking whether 'the chemist, the engineer, or the medical man [has] ever been called unscientific because his research 
and his teaching are directed toward practical ends' $(1954,496)$. For him, then, the scientific character of comparative legal enterprises is not endangered as long as one applies the right method of investigation: '[i]n teaching and studying, it is not the end but the method which determines the scholarly nature of the undertaking' (ibid., 496). Schlesinger proposed such a method - the case or the factual method - for both pedagogical and epistemic reasons. First of all, he was worried that introducing new methods of teaching in a comparative law course in the United States would expose students to too great a degree of novelty:

[s]ince the subject itself is foreign and unfamiliar, it seems particularly important not to increase the beginner's discomfort by introducing, at the same time, an unfamiliar method of teaching. I submit, therefore, that there are strong educational reasons for using the method in which the students are generally trained, that is, a modernized casebook method in North America, and the lecture-textbook method, with whatever enlivening features have been added recently, in most other countries. (ibid.)

Second, as legal terminology differs from country to country it made sense to Schlesinger to trace the solutions that different national laws offered to the same factual situation. This method was largely embraced by comparatists (Schlesinger himself tells us that 29 reviewers approved of his method) having echoes to this day. For instance, in an article from 2009, Jaakko Husa also proposes to teach comparative law on the basis of practical questions (Husa 2009, 923), something that resembles the factual approach developed by Rudolf Schlesinger at Cornell (1968). He cautions that such theoretical questions as 'what is comparative law?', 'what are its purposes?', 'what are its methods?' could in fact block the student's mind, while other more practical questions such as 'is the administration liable on the same basis as the individual?' would function as incentives to learn to think pluralistically as the students will be confronted with a range of responses stemming from the various systems. Schlesinger is cautious to mention that the 'practical motivation in teaching comparative law, [...] does not detract from the scholarly depth of penetration' and adds, therefore, that 'the pursuit of practical goals [is not] inconsistent with the postulate that the teaching of comparative law be a road toward deeper insight into the nature, the history, and the socio-political implications of law' $(1954,499)$. Despite this promising statement, research, and correlatively, teaching, in comparative law has remained for many decades, and largely to this day, black-letter-law-centred (Legrand 2015). The cultural context of law was either completely ignored or dismissed as ancillary and, in any case, easy to acquire. Therefore, it was not considered to be an issue of serious theoretical and didactic concern. As noted even in the 1950 s by a more critical voice, '[a]s new courses were added to the curriculum, they were laid out in the same old format, without consideration of essential differences in their subject-matter or of the effect of monotony upon student reactions' (Wirtz 1954, 257). Exclusionary statements putting forth law's autonomy, all too common in the field of law tout court, now transferred altogether to comparative law, although the intervention 
of comparison should have been expected to suspend regular accounts of normativity: 'when dealing with two distinct legal orders, it no longer makes sense, from an intellectual point of view, to address the same typical normative questions raised within the confines of national scholarship' (Mercescu 2019b, 46). And yet one could read claims precisely to the contrary:

Although the study of law as a social institution is an important topic, it belongs to the realm of social science, rather than to the curriculum of a law school, inasmuch as such a study deals with the law as an aspect of social behavior. It must be assumed that a law student has already obtained during his college years some knowledge of the place and function of the law in human society; a [comparative] law course should study the law from within and in itself rather than in relation to other human standards of conduct. (Sereni 1951, 776)

When the role of culture was, nonetheless, recognized in the literature written around the second half of the 20th century, it was not taken seriously enough to warrant an appraisal in terms of its pedagogical implications. For instance, one author admitted the importance of understanding the foreign culture in which the law is embedded only to add that 'many of us can learn the bare essentials of a culture by travelling, conversations with visitors, correspondence with friends abroad, and by reading good books. That is easy enough' (Mueller 1958, 65).

Another aspect of the early literature on the teaching of comparative law is worth mentioning. Many authors, in what might seem today, in retrospect, as a forward-looking move, argued for an all-pervasive comparison, that is for comparative law not necessarily as a standalone subject but as a method, a reasoning technique pervading all legal subjects (see, for instance, Mueller 1958). While the idea of teaching almost all legal subjects comparatively can only be welcomed by a comparatist of law, in those times and context the assertion betrays, in fact, a rather poor understanding of comparison's stakes and associated complexity. Indeed, many authors tended to view comparative law as a method rather than a field of inquiry in its own right (de Francisci 1921, 426; Gutteridge 1949, 1). The immediate consequence on the pedagogical front was that professors ignored a series of issues that have come to be considered salient features of comparative law to be taken into account in research as well as in teaching. The single most important problematic matter was deemed to be the amplitude of the study materials, while other complex topics such as law's translatability or the interpreter's objectivity did not retain the comparatist's interest or were dealt with in passing, that is, in merely a few sentences. Despite the field's originality, it seemed that little effort was put into departing from the received manners of thinking and of teaching. To take just one example, Sereni could state that 'the notions relating to the foreign should be offered in condensed form' (1951, 778).

The publication of Hein Kötz's and Konrad Zweigert's book, An Introduction to Comparative Law, first in German, in 1969, and then in English translation, eight years later, prompted a new wave of reflection on what it means to do and to teach 
comparative law (1998). In his article from 1975 dealing with the teaching of comparative law, George Winterton identifies four categories of objectives for the study and teaching of comparative law: practical, sociological, political and pedagogical (1975, 69-118). By practical reasons, Winterton understands the need to transmit knowledge on various foreign legal systems that will assist either national lawyers working for big law firms and who are involved in transnational projects or international lawyers. Viewed in this light, comparative law is to be taught for the purpose of developing public policy as well.

Many lawyers - especially Americans - are required to formulate policy throughout their professional careers in legislation, government, on the bench, at the bar or in business, and such an important part of the lawyer's work should not be ignored at law school. Comparative law enables many aspects of policymaking to be taught and, beyond that, can teach the law student much useful data on which to build future research. Additionally, many law students come to law school with the desire to use their professional careers to 'restructure society' (ibid., 107).

As regards another practical objective, the uniformization of laws, the same author is more sceptical about the value of such an enterprise insofar as it 'require[s] such detailed and specialist knowledge that it is not feasible to include the training of comparative lawyers for such work among the purposes of the law school's undergraduate curriculum' (ibid., 106). Other authors have indeed claimed that comparative law can have a place in law school only if it manages to make itself relevant for practice: 'It is my earnest contention, therefore, that the scholarly level of our teaching will not be depressed by an open avowal and promotion of the practical ends which are necessarily pursued by future as well as present members of our great profession. Nor is the pursuit of practical goals' (Schlesinger 1954, 496).

Winterton attributed to comparative law teaching a sociological objective as well, by which he meant the exploration of 'the world's legal systems with a view to establishing general principles relating to the role of law in society' $(1975,109)$. The idea behind this is that by looking at various legal configurations one can, first, realize that our own categories of thought are not universally valid and, second, understand better how law relates to other sectors of our lives, such as economics, history, religion. According to one understanding, studying a multitude of legal systems will reveal to us that we are inevitably inhabiting a world of conflicting values; by contrast, engaging legal diversity is a means, according to some other opinions, to arrive at the core of what law is, to understand the fundamental principles of law that are supposed to hold true across all spaces, to bring to the fore the inner logic of the law, in other words to reduce legal variety to a common denominator supposed to somehow capture the essence of the law. In terms of teaching, the first perspective might translate into a more flexible approach, one that allows students to treat different topics rather tentatively without searching for big answers, a perspective that, bearing in mind that there is no Archimedean point from where a totalizing perspective is to be had, will make room, from one year to another, to other texts and other cultures (for a symbolic understanding of the curriculum in law, see the contribution of Czarnota et al. 2018, 128). This is in line with Csaba Varga's statement, according to which 
the discipline of Comparative Legal Cultures has never been understood as just a series of responses to a previously codified list of questions, but as the ever continued questing for building blocks or structuring components (...) that may specify the (...) genuineness of any given legal culture, contra-distinguished from all others. (Varga 2020b, 27 - original emphasis)

The other perspective would assume, by contrast, that there are some conclusions to be reached, some legal systems to be studied and therefore some set texts to be necessarily read.

A course on comparative law could also play a political role. To the extent that it encourages students to give up their prejudices and embrace an informed (not necessarily agreeable) perspective on foreign cultures, it certainly 'leads to the breaking down of parochialism and narrow nationalism' (Winterton 1975, 111). It has been suggested that the political goal of comparative law can be taken further so as to eventually amount to a sort of proselytism (ibid.). According to this paradigm, underdeveloped countries should offer comparative law courses in order to teach their students how to approach legal reform through legal imports, while leading countries such as the United States should offer the same courses in order to teach their students, conversely, how to go about legal exports. For instance, two American authors maintained that '[i]t is in our self-interest to assure that [social change and modernization occur] through orderly political and legal processes' (Seidman and Thome 1968, 362), echoing the words of former Justice of the Supreme Court, Sandra Day O'Connor: '[w] hen US Courts are seen to be cognizant of other judicial systems, our ability to act as a rule-of-law model for other nations will be enhanced' (O'Connor 2003).

David Kennedy denounces contemporary comparatists' political numbness, contrasting it with their pre-war peers' political engagement: '[a]ll [comparatists before WW II] felt comfortable participating in public life, making choices and advocating positions on issues facing government on the basis of their comparative knowledge' (Kennedy 2003, 373). By contrast, in the contemporary landscape, ' $[\mathrm{t}$ ] he discipline encourages its practitioners not to take positions on issues facing government and to think of their professional work as the exercise of academic good judgement rather than political choice. Comparative law today is about knowing, not doing' (ibid., 346). Departing from the prevailing vocabulary imbued with agnosticism, this author pleads for much more visible political commitments from those working in comparative law, a claim he bases on the intuition that the profession does more to sustain than remedy the world's status quo injustice' (ibid., 433).

Finally, according to Winterton, comparative law can ultimately be about skills (as opposed to content), in which case it undertakes a pedagogical mission. Indeed, comparative law could be just the right place for students to acquire the soft skills for which the other, more content-centred subjects have no time (in-depth hermeneutic analysis of texts, teamwork, interpretation of sociological data, writing skills or critical thinking). In general, professors of comparative law are well aware of their discipline's pedagogical potential, especially because it is well known that 
law curricula are laden with dogmatic subjects that focus on the transmission of brute knowledge paying scant consideration to the development of relevant skills. However, to what extent this awareness ends up translated into practice remains far more uncertain.

\section{Teaching Comparative Law Today}

Various inquiries into the current state of affairs in comparative legal education show that some of the old habits persist, although, epistemically speaking, comparative law started to put on new garments. In this context, there is scope for arguing for a renewed education, more in line with comparative law's theoretical advancements. This is not to suggest that some teaching techniques are 'good' or 'bad'. It is clear that they underpin different epistemological views and are therefore as good or as bad as these. And it is certainly not to suggest that higher education, no matter what the discipline is, is to pursue an identical path. While we can generally agree on the purpose of primary and even secondary schools, when it comes to the role of universities, the meaning of education becomes immediately a source of dispute to the point where it has been affirmed that if the university is in crisis, it is essentially a crisis of identity' (Reboul 2010, 43). Should universities transmit to its students broad, humanistic knowledge in order to cultivate their spirit or a set of skills ready to be employed in professional practice? Should universities focus on research over teaching? Should research be fundamental or applied? Should universities propose specialized training or multidisciplinary knowledge? As British sociologist Frank Furedi argues,

such questions have been raised and re-raised through the centuries, so it is not surprising that the twenty-first-century public continues to argue about the meaning and aim of education. What is new, and in many ways unprecedented, is that the contemporary discussion of education is not confined to a debate on the basics but touches upon virtually every aspect of schooling. (2009, 6-7)

American philosopher and educational reformer John Dewey (1859-1952) famously pointed out 'the futility of trying to establish the aim of education some final aim which subordinates all others to itself' (2004 [1916], 106). 'As [a] matter of fact', Dewey argued, 'a large number [of aims] have been stated at different times, all having great local value. For the statement of aim is a matter of emphasis at a given time' (ibid.). Nonetheless, in full respect of the diversity of aims and correlative ways of instruction present or future, one can still talk about a series of strategies more conducive to the vision of comparative law that I praise as intellectually rewarding, epistemically convincing and pedagogically meaningful. 


\subsection{The Non-Dogmatic Teacher}

The way a teacher will act in his or her teaching depends on the conception he or she holds with regard to law, on the one hand, and his or her vision of higher education and academic freedom, on the other. First, the legal scholar in the continental tradition believes that law is a science and that when he writes about law he writes about something that purportedly transcends himself qua interpreter and possibly even time and place to the extent that 'law is viewed as being [...] relatively immune to social and political forces' (Bix 2003, 985). Even as positivism - roughly understood as a strong epistemic commitment to finding correct answers through proper methods of investigation - had fallen out of fashion in many disciplines, it continued to hold sway in the field of law (Atias 1988, 347). Today, it is no exaggeration to claim that many positivist writers on the law (especially in the civil-law tradition, which has hardly known the various 'law ands'), and, following in their footsteps, disciplined comparatists of laws as well still adhere to a

brand of writing purporting to present itself in an unproblematic and unsituated mode, seeking to deny any political commitment or personal investment (thus, wanting to show itself as being 'simply' there rather than as having arrived where it is through processes of contestation with alternative practices). (Legrand 2019, 113)

Thus, when entering the classroom it will be tempting for this scholar to present all the knowledge he or she wants to transmit as given, letting students know that there is knowledge 'out there' to be had, to be apprehended in a 'neutral' manner, not unlike the act of merely grabbing a cup of tea from our desk. However, Dewey did well to remind us that 'simple scholarship is not enough' $(1916,191)$. I claim that comparatists should renounce this unreserved attitude and bring into their pedagogical practice what Carol Nicholson calls the 'pragmatic temperament' (2013, 250). Quoting the words of Italian pragmatist Giovanni Papini, who wrote in 1906 that '[w] hoever gives a definition of pragmatism in a few words would be doing the most antipragmatic thing imaginable', Nicholson cautions against unduly reifying pragmatism and proposes instead to retain 'a broader view of pragmatism as a habit of mind that is open to uncertainty, change and different points of view' (ibid., 250). Thinking about pragmatism in the adjectival form (thus praising the idea of a 'pragmatic temperament') would be more advantageous, for educational purposes included, to the extent that pragmatism is not a set of doctrines but rather an approach:

Peirce, James and Dewey disagree in many of their philosophical views, but they all agree that the pragmatic approach can best be described as a habit of mind, an attitude, or a disposition of being open to new ideas and experiences, rather than as a definitive solution to philosophical problems. (ibid. 254) 
While emphasizing that a pragmatic attitude towards knowledge does not imply the belief that anything goes, Nicholson takes the example of training doctors and pilots to show how teaching scepticism towards dogmatic certainty improves highly complex decision-making processes. Far from undermining the effectiveness of their practices, this culture of suspicion increases the chances of good cooperation among, and therefore better outcomes for, professionals.

But how would this 'pragmatic temperament' translate into the actual teaching of comparative law? Besides an obvious need for adaptation in terms of the professor's language (for instance, the use of a personal tone), another step in the direction of cultivating a non-transcendental attitude towards knowledge would be for a teacher to express overtly - in the classroom, that is - the many ways in which 'culture "has" [him/her]' (Legrand 2019, 106). Indeed, the comparatist is never autonomous or objective, which does not mean that he or she is arbitrary either (the teacher interprets legal and other materials that have inscribed on paper these words and not those words). But it is to say that personal experience and cultural inscription do colour one's rendition of these materials' significance. One's pedagogy, no less than one's research, should make clear that in the construction of knowledge one makes choices, some of which are certainly related to one's biography. They are one's own way. I rely here on Pierre Legrand's explanation of the Heideggerian concept of 'way' (Wege):

Crucially, a way neither begins nor leads anywhere in particular. It has no origin in the sense that from the moment one dwells on earth, one is always already underway (...). And it has no point of arrival in as much as thought, which must be incessant questioning, eschews solutions. (Legrand 2014b, 291 - reference omitted)

Importantly, then, the comparatist is to pave the pedagogical way for an acceptance of the professor's way as exactly that: one path among other possible paths. And whether this particular way is consonant with the professional community's ways to which the professor is deemed to belong shall also have to be made explicit. With its visible clash between a stubbornly resilient orthodoxy and an indefatigable heterodoxy, comparative law can indeed represent an early and quite straightforward exposure of students to the nexus between knowledge and power. Thus, through his or her course, the professor is to show that the legal community and its discourses do not operate by the force of logical necessity. What appears as a rational development inside a profession might in fact be the translation of consensus built through the inertia of tradition or through persuasive strategies that are not free from any form of authority (I have in mind such contingent elements as the charismatic presence of a leading voice, their credentials and affiliation, the visibility of the publishing house having hosted their works, networking, etc.). This move away from positivism's scientist stillness must lead, I wish to argue, to the espousal of a different conception of academic freedom from the one that currently holds in law, at least in the civil-law tradition. Before a researcher starts his or her investigation it is important that he or she reflect on what vision of aca- 
demic freedom they want to make theirs, for this choice will inevitably lead to different epistemic possibilities. Indeed, if comparatists are to conceive courses that honour both the teacher's and the disciple's responsibility towards society, they should be ready to give up the one version of academic freedom - cynic and complacent - that encourages the policing of borders and insists that good academic speech be value-free academic speech. In what follows, I will therefore discuss several conceptions of academic freedom to then highlight the one that seems to be the most appropriate for the scope of comparative legal studies.

In a book making an inventory of the various conceptions of academic freedom and their underlying moral and philosophical rationale, Stanley Fish pleads for understanding academia's mission as subject to the control of the specialized community to which the faculty belongs (Fish 2014, 20-37). Fish refuses to found academic freedom on a value external to the academic world, such as the public interest. For him, in line with the view that sees modernity as the result of functional differentiation, if we are to protect the university from politics, for instance, we should act accordingly, not because we are dealing with a special community (that would fulfil an exceptional role in society) but with a specialized community (that has its own, specific function). The researcher is then invited to move freely within the framework fixed by his or her own discipline, which is specifically academic and not economic, political or other. Fish accepts that this framework has nothing natural or universal about it, that it is a product of historical contingency, of arbitrary decisions tracing a clear line between academia, on the one hand, and politics or economics, on the other. Moreover, he is willing to admit that the manner in which the researcher conducts his or her research necessarily derives from his or her personal background and current intellectual affiliations. Nevertheless, Fish appreciates (without having recourse to notions such as 'objectivity' and 'neutrality' that he deems inadequate) that it is precisely the researcher's duty to embrace this distinction between the academic world and any other world, political, economic and so forth, no matter how artificial the distinction is in fact. He labels his vision the 'It's just a job' school of thought.

In stark contrast to this, Fish presents the 'Academic Freedom as Critique' school of thought, which breaks with the understanding according to which a researcher's freedom needs to be apprehended in the light of the standards agreed upon by the members of a given disciplinary field. For the American philosopher Judith Butler, this disciplinarizing vision of academic thought forecloses the possibility of a subversive gesture meant to 'unsettle the boundaries' $(2009,774)$ : 'as long as voices of dissent are only admissible if they conform to accepted professional norms, then dissent itself is limited so that it cannot take aim at those norms that are already accepted' (Butler 2006, 114). According to this author then, the scope of academic freedom consists in defending dissidence, including that form of dissidence calling into question the separation between academia and what is traditionally considered to be the realm of politics. Indeed, as R. Radhakrishnan (2008, 503) writes: 'Aren't outsides and insides always reciprocally relational and mutually constitutive such that there can be no absolute and non-negotiable forms of exteriority and interiority?' Consequently, we might ask ourselves with Radhakrishnan whether there is any freedom that would be specifically academic 
(ibid.). Under this paradigm, freedom of research should rather be construed from the point of view of critique (both in a positive and in a negative sense) and therefore attributed to the individual as a standalone thinking subject and not to the individual as a member of a community of thinkers. Following Michel Foucault, Butler $(2009,788)$ rightly explains that the critical posture required from the researcher signifies, on the one hand, that he or she refuses to submit to an established authority (the negative dimension of critique) and that, on the other hand, the researcher, by revolting against orthodoxy, expresses his or her 'self': 'disobedience is linked to self-invention' (the positive dimension of critique) (ibid.).

The main features of legal education in the civil-law tradition lie with its self-contained language and positivist commitment understood as a propensity to look for law only in traditional legal sources to the exclusion of any 'foreign' materials (sociology, economics, philosophy, etc.). Following Fish's view, then, anyone in the legal field who would advocate for the use of such resources or would effectively employ them would be acting outside the confines of academic freedom because there is a general consensus within the community of lawyers that 'contaminating' law - which is supposed to be neutral - with other disciplines amounts to entering the controversial field of politics and therefore expressing a biased view. I argue that academic freedom should protect political interventions of this kind for I do not understand the political as a "strict separation between "ours" and "yours" or, in its most radical expression, a strict separation between friend and enemy' (Cerar 2009, 20) but as a reflected upon choice between 'conflicting alternatives' for which 'no rational solution could exist' (Mouffe 2005, 10). Under this paradigm, academic freedom means 'critical sensitivity', that is, an 'awareness of the potential issues that arise in inquiry, a sensitivity to the contingencies that arise in the scientific process, and a recognition that value judgements must be made as part of settling those contingencies' (Brown 2020, 237).

Thus, let us imagine that the law professor decides to discuss during classes a controversial case involving a woman's claims against her employer based on allegations of discrimination. Should the professor, a woman herself, side with the employee using aggressive language against men, her behaviour could be easily deemed to be outside the scope of academic freedom. By contrast, should the professor decide to present to her students a feminist reading of an apparently neutral statute to be used in the defence of the employee, her intervention, though political for it brings into law political considerations, should remain, in my view, under the protection of academic freedom. Ideologies, whether we like it or not, are inscribed in the various legal artefacts lawyers deal with. To excavate them by practicing a 'hermeneutic of suspicion' (Kennedy 2012, 40) is not to betray law by acting politically but to make sense of law by acting epistemological(ly)-wise. It is also to become more sensitive to one's moral responsibility: 'being value-free is not generally a virtue, and indeed, it can amount to being irresponsible' (Brown 2020, 236).

Academic freedom promotes, undoubtedly, legitimate expectations in its desire to keep politics at a remove from the construction of knowledge. This does not mean, however, that it should entertain illusions about how knowledge is actually constructed. As a matter of fact, academic freedom should be conceptualized so as to 
enhance the law professor's capability of explaining as illuminatingly as possible the very complex relationship between knowledge (here law) and politics. Or this is not something that can be done from 'the traditional within' of law, so to say, using the classical, dogmatic, legal tools.

One can see, then, that the professionalizing vision of academic freedom conventionally attached to law - possibly attractive in times of 'peace' - becomes problematic as soon as revolutionary scholars would want to wage a war with regard to the boundaries of a given territory. Therefore, academic freedom should be understood as 'protect[ing] the teacher not only from outside the university, but also from the university itself (and other professors)' (Bryden and Mittenzwei 2013, 314).

Now, I have argued that the comparatist as teacher cannot escape from his or her cultural embeddedness. Inevitably therefore, comparatists 'engage in a similarization exercise' when, trying to tackle foreign law, they re-signify it so that it fits their own legal predispositions and assumptions (Legrand 2014b, 294). As Legrand puts it, '[a] language of apprehension assuming the kind of hegemony that feels able to dispense with other-knowledge, thus masquerading as the provider of epistemic appreciation where there is in fact misrepresentation, cannot but generate significant ethnocentric concerns' (ibid.). How, then, are comparatists of law to engage with legal alterity respectfully or, in any case, less ethnocentrically? Imagine a tree. Imagine its roots to be so deeply ingrained that it is literally impossible to take them out. Let us suppose that as the tree grows new branches emerge. Some will remain just that, branches on a tree, but some will make their way towards the ground in order to pierce the soil and take root. That is the new, significant, knowledge that we acquire and that will fuel our future thought. It is the knowledge on which future knowledge will be grounded. But remember that as these new roots make a place for themselves in the underground, they do not have the power to completely displace the old roots (the old knowledge). At most, they will force these old roots to shift, more or less. Thus, foreign law does not displace domestic law. Rather, foreign law and domestic law will be co-present but in such a fashion that the anteriority of one in relation to the other in the mind of the comparatist will bend the trajectory of learning in specific ways. The old and new will blend in a process of negotiation that will only ever allow for so much authenticity of that which is other. To put it differently, the task of the comparatist is to lay the ground for a 'reception' of foreign law that is as 'hospitable' as possible. Or hospitality, as the name indicates, has something to do with mental - but also and importantly - emotional availability. It has been rightly pointed out that 'modern comparative law originally sought detachment in appeals to the adoption of scientific method' (Brooks 2007, 4; for a critique of method in comparative law, see Glanert 2012). For instance, comparatists strived to rigorously classify the various national laws into legal systems as if taxonomies speak (objectively) once and for all or to rank laws according to allegedly neutral, economic, criteria. Or, as 'the effort to classify legal regimes fails to grasp the complex historical and social interrelationships between legal systems or traditions' (Brooks 2007, 4), so the effort to rank national laws fails to grasp the complex historical and social interrelationships between law and economics (or, for that matter, other disciplines) 
(Muir Watt 2009). Hospitality is therefore not achieved through the appearance of solid intellectual preparations. To the contrary, for it to come about, it requires involvement, struggle, commitment, passion and, ultimately and maybe somewhat counterintuitively, scepticism.

Richard Brooks describes how Hellenistic knowledge (via its schools of cynicism, scepticism, stoicism and epicurism) can contribute to educating comparatists in detachment (understood not in its typical scientific sense but as an exercise in diminishing the excessive attachment to one's own categories of thought, thus creating the necessary premises of a meaningful interaction with the other).

Pyrrhonian scepticism (named thus after Pyrrho, considered to be the initiator of the sceptic school), for instance, could guide the comparatist towards 'a sense of relativity [commanding that] no one legal regime is superior' (Brooks 2007, 10). Brooks gives the example of teaching the new Iraqi constitution to American students. In the face of shock among the students at the mention of the role of religion and women within Sharia and in the constitution, one step could have been to review the history of the Equal Rights Amendment in the United States to show how many of the feminist achievements were in fact obtained at the expense of reinforcing racial segregation or to unveil 'the fact that a substantial minority in this country and a majority in some states held positions opposed to the recognition of formal equality between the genders' (ibid., 15). Such an example 'might begin to sober the students' and prepare them emotionally to receive the other (while maintaining their ability to critically appraise what they see and hear and learn) (ibid). Brooks invites comparatists to learn from Cicero and his 'academic scepticism': 'unlike the Pyrrhonian skeptics, the academics eventually would adopt one set of belief as merely probable. Cicero embraces such academic skepticism in many of his writings, laying out the pro's and con's of various philosophical doctrines' (ibid.). Specifically, 'the recognition of different legal regimes and laws can lead to the listing of their advantages and disadvantages - a process which precedes the tentative embrace of one or another legal system or law as a "probable" good regime or law. The emphasis here is in the tentativeness with which one adopts any one system or law', or, broadly speaking, the tentativeness with which one approaches knowledge in general (ibid. 10).

In classical education, the professor is there to transmit knowledge as if he or she were a mere conduit sorting a predetermined, true, understanding from a box and moving it intact to a different box lying with the students: '[i]n this tradition the truth claims of legal knowledge are not only treated as unproblematic but are rarely raised in education at all' (Thomson 1987, 184). Accordingly, students will be most likely presented with coherent accounts of foreign law and a clearcut assemblage of similarities and differences between two or more laws. I urge comparatists to draw inspiration from the critical legal movement when it asserts that

not only does education tend to be taken more seriously, but the boundaries between research and teaching and between frontier and well-established 
territory become increasingly blurred and [...] the truth claims of traditional legal knowledge are rendered explicitly problematic.

While this might not be true for other less-related-to-language disciplines, 'legal discourse is in a state of constant flux: its meaning shifts depending on the language in which it is expressed and even depending on the reader' (Harvey 2002, 182). Or 'no matter how talented a wordsmith the reader happens to be, the words always have more meaning to yield than can ever be ascribed to them' (Legrand 2019, 306).

Because a text consistently exceeds the limits of any rational reporting, 'there is no total reading, no reading of the whole' that is ever possible. Indeed, since not all its interpretive potential can be released - there is always more that a reading can make words say - the foreign law-text will inevitably feature an interpretive remainder, which shows how a text is a writhing, living force, how the text is ever in the process of becoming - a text is not, it becomes (ibid. - original emphasis).

Therefore, the comparatist-professor should feel authorized, despite warnings to the contrary to be found in the older literature, to bring his research agenda up for discussion with his or her students. For Schlesinger, indeed, the teacher who 'rides the hobbyhorse of his own research interests' is not a good teacher (1954, 494). However, it is very doubtful whether the teacher who commits to teaching comparative law on the basis of materials and texts selected according to criteria extrinsic to his or her own desires and interests will yield much better pedagogical outcomes. One can only wonder how he or she is to retain enthusiasm in the course of teaching for, while scholars are generally reluctant to admit their disinterest towards particular subjects, it surely cannot be the case that they take an avid interest in everything. Or 'it makes no sense to confine the curriculum to the cognitive when the body and its emotions are so important' (Garrison and Neiman 2003, 24). Indeed, comparatists would do well to remind themselves that there is no 'dispassionate acquisition of knowledge' (Frow 1988, 321 [original emphasis]). Flexibility in the design of one's own introduction to comparative law will, of course, mean that comparative law courses worldwide will look very differently from each other, but this is not something to deplore. As students will get acquainted with knowledge in the making, with the becoming of texts and of 'foreign law-text[s]', they will have learnt, above all, an attitude, with their professor as the principal exponent thereof. And so together, they shall refuse to proceed with the self-assuredness that discursively transforms necessarily contingent and localized knowledge into allegedly comprehensive, totalizing and therefore totalitarian/authoritarian knowledge.

\subsection{The Eclectic Materials}

Texts do not speak for themselves. They are made to signify through the input of a reader whose intellectual allegiances, linguistic competences and cultural predispositions will all have a role to play in the fabrication of meaning. But even assuming a most sophisticated reader capable of channelling the text through the most original and enriching of interpretations, not all texts are equal in terms 
of their interpretative potential. Law (comparative law as well) will be manifesting itself at its best through the production of open-ended texts that permit the reader to explore their meaning far beyond the confines of the written word:

the writerly text, by denouncing the illusion of a progressive narrative that would transport the meaning intact from the author to the reader, allows the latter to do more than just read the text - that is, more than mechanically repeat the words of the author. By contrast, at the risk of a certain degree of incomprehensibility (ilisibilité), the writerly text encourages the reader to build in the writing of the author, thus helping reveal its intertextuality (the plurality of the readerly, though not inexistent, is much more limited). (Mercescu 2019a, 316)

While all texts are unsaturable insofar as their meaning emerges relationally (it does not exist as such, but in relation to a given factual situation, other texts, past or subsequent, the interpreter's assumptions), their unsaturability does not make them equally valuable. What texts the professor chooses, then, for the deployment of his or her theoretical arsenal matters just as much as the cultivation of a non-dogmatic attitude among students.

Legal materials should be drawn from both theory (on how to compare) and practice (actual comparisons) and should seek to cover 'the laws as written, the laws as implemented, and the laws in the context of the society' (Waxman 2001, 307). Besides the obvious need to confront students with foreign legal materials, one should not lose from sight the importance of making students deal with extralegal resources as well, all the more so that judiciaries around the world appear to be referencing, more and more often today, non-legal sources, ranging from poetry to history books, from newspaper articles to treaties of psychology. In discussing the curriculum of his comparative course, Michael Waxman explains that he uses 'film (particularly foreign and domestic movies and other video recording), literature, and sociology texts (particularly foreign and domestic nonfiction cultural histories)' (ibid). Precisely because the assignments are drawn from multiple disciplines, 'the course can complement many "law-and" courses and benefit from seminar-style issue analysis' (ibid). Indeed, what Henry Remak claimed in 1970 about comparative literature seems to me to be equally valid as applied to comparative law today:

Comparative literature is the study of literature beyond the confines of one particular country, and the study of the relationships between literature on the one hand and other areas of knowledge and belief, such as the arts (...), philosophy, history, the social sciences (e.g., politics, economics, sociology), the sciences, religion, etc., on the other. In brief, it is the comparison of one literature with another or others, and the comparison of literature with other spheres of human expression. (Remak 1971, 3) 
In fact, empirical studies show that students who were in contact with other disciplines do have a more critical outlook on their legal education. ${ }^{1}$ This points to the value of interdisciplinary work, especially for a domain such as law that is closely linked to so many other areas of our human existence. Insofar as 'good teaching requires moral and aesthetic, not just cognitive, perception of the needs and abilities of the student' (Garrison and Neiman 2003, 29), the presence in law of these other discourses facilitates the transmission of knowledge that is not purely cognitive, but also moral, emotional or aesthetic.

Resources, be they legal or other, need not be all so difficult as to dissuade students from thoroughly engaging with foreign law and comparative legal theory (for a deliberate simplification of highly sophisticated ideas relevant for comparative law, see Legrand 2009). However, at least part of them have to read uncomfortably enough for students to experience a deterritorializing effect as they pursue their studies, that is to make them renounce the totality of thought that commends to see domestic law as the only law 'out there' and its categories as 'natural' entities. Thus, students will have better understood that comparative law is more than just an 'intellectual fad' (Legrand 2014a, 346) or a cabinet of legal curiosities. It will have been displayed as an intellectual enterprise that it takes effort to accomplish. Ideally, then, among the various texts, the professor could include at least one text formally belonging to another discipline and at least one legal text in a foreign language in order to raise awareness among students about the challenges of disciplinary and linguistic translation. Additionally, students might be requested to work themselves on a legal translation and thus be made to get lost (and, importantly from a pedagogical point of view, frustrated) in translation.

In any case, texts that merely juxtapose the different laws on a specific matter shall not be deemed adequate for a comparative law course to reach the subversive mission it should have if one is to take a critical perspective. As comparison enters the toolbox of the legal scholar, it calls for a rearrangement of the objectives of legal research, for it must be that the other's presence is more than a graphical presence and also more than an instrument of self-legitimation. In the presence of the other, the self can no longer credibly represent itself as a totality, a hermetically sealed, coherent system. Accordingly, comparative law, if it is to be a serious intellectual endeavour, should move away from the type of operations with which lawyers are traditionally concerned:

Legal technique and rationalization of legal technique; fostering legal dogmatics through the organization of the different rules adopted by the sovereign in the form of an orderly, coherent and systematic representation; seeking to offer an interpretative commentary of the legal provisions in force that would be judicious and rational, that would explain their reach and their potential, that would eliminate or reduce their apparent flaws, obscurities, gaps, or contradictions; pursuing fixity of meaning. (Legrand 2019, 113) 
By contrast, comparative law forces the laws under investigation to descend from their abstract categories of thought and their formal logic back into society. For this purpose, irrespective of their format (a video recording, a statute, a newspaper article, a dictionary entry, a legal decision, an economics text), the materials to be studied have to be able to 'puncture law's metaphysical balloons' (Posner 1990, 1663). In Britain, the little book entitled Learning the Law, by Glanville Williams, epitomized the formalistic attitude in that the 'author even doubt[ed] whether students may criticise the law' (Thomson 1987, 183).

\subsection{The Undisciplined Student}

No matter how critical the professor is and how eclectic and writerly the materials are, nothing satisfactory can be achieved without the students' contribution. Or as early as their first semester of law, students are socialized in an exclusionary cognitive universe, that is an epistemic world that excludes every possible other (foreign law, foreign languages, foreign disciplines, foreign authors) and styles itself as precisely that which is not economics, politics, art, culture, etc. by implausibly decreeing its autarchy. It is, therefore, not easy to de-disciplinize the student's mind, one, moreover, that has been proven very quick to let itself be imbued with the positivist world view. There are many reasons for why disciplinarization in law is so successful. While this is not the place to examine them, I wish, nonetheless, to speculate on the following explanation: owing to its autonomous language, law is accessible, like the more technical disciplines, to students of all backgrounds. No matter whether you have read by the time of your enrolment in law school Aristotle, The Odyssey or The Wealth of Nations and no matter how good or bad you were at calculus, you can still understand and apply the logic of law. While warnings to the contrary abound from established practitioners and academics alike, for lawyers enjoy boasting about their sophistication and relevance, law is nevertheless, in this sense at least, easy. Having read no book whatsoever, chances are that students will have a hard time in a philosophy department. Having no practice or talent for mathematics, again, chances are that students will find them difficult. In the form taught today in most faculties across the civil-law world, at least during the bachelor's degree programme, law requires no more than good memorization skills and plain logic. It is not surprising, then, that students feel reassured by such doctrine as positivism, which basically tells them that they can master law without any recourse to the social sciences, to history, to economics and so on and so forth. Moreover, as, paradoxically for a professional discipline, practical activities like writing legal documents do not rank high on most law schools' agenda, students are encouraged to believe that writing in the law is, again, autonomous and cannot possibly benefit from the insights of humanities, for instance. This leaves students with a feeling of reassurance and satisfaction.

Against this very disciplined background, comparative law, critically taught, can present itself to students as no less than shocking, and this, in turn, can lead to a loss of interest and ultimately to complete divestment on their part. Therefore, the professor will have to imagine a series of strategies meant, as I said quoting 
Posner, to 'puncture law's metaphysical balloons' while staying manageable from the perspective of students' capabilities. Encountering alterity, for instance, is an unavoidable topic in comparative law and, what is more, one that is unavoidably complicated (for a pedagogical scheme trying 'to bring the other very close "without becoming any less far away" and thereby to suspend the othering power of the sovereign self', see chapter 5 of Frankenberg 2016, 76). The professor has, of course, the option of assigning to students an edited volume dealing with alterity from various disciplinary standpoints. The task of making students grasp the full complexity of such a topic can nonetheless be alleviated by recourse to at least two complementary routes. One would consist in inviting students to read a novel that would convey important messages related to the topic of identity, belonging, foreignness, being abroad or homecoming. Another measure would reside in making it compulsory for students to experience alterity on their own, in real life. Thus, a research sojourn abroad would be a significant component of any serious comparative law module.

Because comparative law as critique of mainstream legal theory and education should not be understood to want to seize on the power that it seeks to dismantle, students should be encouraged to think of other discourses, from within or outside the law, that contradict the traditional or, for that matter, the revised tenets of comparative law. For instance, one assignment could entail a collaborative project between comparative law students and their colleagues studying international law, a field that might look at topics such as the uniformization of laws, for instance, through a very different angle.

For comparative law not to share the tragic faith of 'the-optional-courses-outthere-to-be-forgotten-as-soon-as-the-semester-ends', it is highly important to include a comparative dimension in the more traditional courses as well. The early comparatists dreamt, indeed, of a ubiquitous role for comparative law, partially because they underestimated the complexity of the enterprise. Now that we realize the full extent of the task lying before us, we can plead for an extensive, integrated, comparative education on the condition of also allowing for a standalone comparative legal theory course.

Having reached the end of my article and given its title, I feel I should make two additional points concerning the relationship between pragmatism as a philosophical strand of thought and comparative law as a juridical discipline.

First, it should be noted that my contribution did not seek to establish the relevance of pragmatism for legal or comparative legal scholarship. Some authors remain sceptical about the possible input pragmatism might have in the legal field, accusing this particular line of thought of theoretical emptiness (Tamanaha 1997) and therefore insufficient guidance to 'the crisis concerning legal interpretation in a pluralist society' (Rosenfeld 1998, 327) or mere instrumentalism (Dworkin 1991). Others have tried to show that pragmatism has important merits as applied to law. For instance, with its emphasis on context, consequences and values (understood as practice based rather than either given by nature or identified by reason) alike, pragmatism is viewed by Sanne Taekema as providing a useful 'way out of the debate between legal positivism and natural law theory' $(2006,34)$. For David Landau, pragmatism 'might fit into existing jurisprudential approaches 
that are important for comparative constitutionalism' (2018, 222). Specifically, this author argues that 'both proportionality [as a strategy of adjudication] and pragmatism [...] tend towards solutions that are achieved by weighing conflicting principles and interests in a concrete factual [...] context' (ibid., 223). Thus, 'rather than reasoning abstractly or by analogy from existing legal concepts [...] legal pragmatists call for a problem-solving approach that might rely on a number of different bodies of knowledge' (ibid., 211). Unsurprisingly, then, 'receptivity to non-legal information (such as political science, economics, psychology or the hard sciences) is a ubiquitous prescription from pragmatist judges' (ibid., 216).

This is not the place for me to engage in what undoubtedly constitutes a debate with many faces. Nonetheless, even while refraining from explicitly embracing here any one view in the direction of law's compatibility or incompatibility with the tenets of pragmatism, I think it is still possible to assert the usefulness of a pragmatic approach to the related question of comparative legal education. For sure, in doing so, it is hard not to imply a stance vis-à-vis the relation between pragmatism and law tout court. Indeed, I have argued that a pragmatic temperament is necessary for the development of a critical orientation in the teaching of comparative law. This presupposes, among other things, that the student is familiarized with other discourses than doctrinal law. Or to the extent that this student is tomorrow's pragmatist judge who, according to Landau, will employ in her decisions proportionality analysis and, I would add, more and more frequently comparative legal reasoning, it is rather easy to see how the type of attitude inspired by pragmatism that I promote as useful for the teaching of comparative law makes itself useful for the practice of law as well. Now, this point of convergence notwithstanding, it might be that pragmatism and comparative law - in its critical orientation - find themselves in tension from other points of view insofar as the latter, at least as expressed in the writings of Pierre Legrand, takes its cue from deconstruction. An analysis of whether critical comparative theory and pragmatism are in agreement or not hinges, then, on several complex questions such as 'to what extent is critical comparative scholarship really deconstructive?', 'is deconstruction pragmatist all the way down?' and 'is pragmatism deconstructive?' (for a discussion of the last two questions, see Mouffe 1996). But again, these problematics largely surpass the framework of investigation that I sought to propose here.

Second, I find it important to make a remark concerning the distinction between 'pragmatic' and 'practical'. In current discourse, 'pragmatic' is often associated with opportunism, compromise or, more broadly, anything having to do with practical matters (as opposed to abstract or theoretical ones). As such, it can stand in contrast to 'principled' (Nicholson 2013, 264). In its specialized, philosophical, connotation, the 'pragmatic' does not exclude adherence to principles but also seeks to make room for adaptations depending on context so that no knowledge develops into blind ideology. In this sense, at its core, pragmatism stands for 'undogmatic': '[a] pragmatist, as contrasted with an ideologue, can mean a person who is not wedded to a particular school of thought and takes an open-minded approach to solving problems by using ideas from a variety of sources' (ibid.). Consequently, I should make clear that a pragmatist (in the sense of undogmatic) 
approach to the teaching of comparative law as advocated in this article involves by no means a practical (in the sense of untheoretical, problem-solving-oriented) pedagogical outlook. Quite to the contrary, to the extent that the traditional practice-oriented teaching of comparative law was more often than not premised on a series of dogmatic assumptions, ranging from the presumption according to which laws are similar, even as to details, to the idea that comparative law must be put into the service of laws' uniformization, it certainly does not accord itself with the spirit of pragmatism. Indeed, when comparative legal scholarship is instrumentalized for some purpose external to the research itself there is an even higher risk than usual that the researcher mistakenly reads every material through the prism of this overriding goal.

To teach comparative law with pragmatism, then, is not to teach it for some immediate practical purpose but to do so bearing in mind some of the theoretical lessons of pragmatist thinking, by asking oneself permanently, 'What is the broader, social, impact of the ideas I advocate?' The answer can rarely be 'none'. Hence, pragmatism places the responsibility with the researcher 'not only for conscious decisions and actions, not only for dreams, but - in a much wider sense even for the reality created by individual self-fulfilling prophecies' (Watzlawick 1984, 327).

\section{Conclusion}

In many respects, law schools are failing. Because a wholesale reform is not to be envisaged any time soon (the pride attached to the emergence of the university, around law, in 12th century Bologna probably makes many lawyers enjoy and praise what still resembles medieval education), it becomes paramount to change legal education from within the possibilities of the current curriculum. As has been argued, 'there is no single approach or body of theory which can uniquely accomplish this task in relation to law, for what gives the critical project identity is its intent, not any particular intellectual position' (Thomson 1987, 194). Therefore, while comparative law is not uniquely well placed to take up this reformatory goal, it is among the best candidates to start with. Comparatists should remember, then, the pedagogical dimension of their mission and hence shift 'the[ir] emphasis [...] from a concern about what to say about law to how one can provide a critical education through law' (ibid). For this purpose, a pragmatist attitude, where pragmatist is to be understood philosophically as essentially referring to a critical, undogmatic, open-minded vision, should come in handy.

\section{References}

Atias, C. (1988). Judges, Jurists, and Legal Knowledge. Archiv für Rechts- und Sozialphilosophie / Archives for Philosophy of Law and Social Philosophy, 74, 365-385.

Bix, B. (2003). Law as an Autonomous Discipline. In P. Crane and M. Tushnet (Eds.), The Oxford Handbook of Legal Studies. Oxford: Oxford University Press. 
Brooks, R. (2007). The Cultivation of Cosmopolitan Detachment in Comparative Law: The Hellenistic Contributions. Global Jurist, 7(2), 1-19.

Brown, M. (2020). Is Science Really Value Free and Objective? In K. McCain and K. Kampourakis (Eds.), What Is Scientific Knowledge? London: Routledge.

Bryden, J. and Mittenzwei, K. (2013). Academic Freedom, Democracy and Public Policy Process. Sociologia Ruralis, 53, 311-330.

Butler, J. (2006). Academic Norms, Contemporary Challenges: A Reply to Robert Post on Academic Freedom. In B. Doumani (Ed.), Academic Freedom after September 11. New York: Zone Books.

Butler, J. (2009). Critique, Dissent, Disciplinarity. Critical Inquiry, 35, 773-795.

Cerar, M. (2009). The Relationship Between Law and Politics. Annual Survey of International and Comparative Law, 15, 19-23.

Czarnota, A., Pazdziora, M., and Stambulski, M. (2018). The Hidden Curriculum in Legal Education. Krytyka Prawa, 10(2), 114-129.

Dainow, J. (1951). Teaching Methods for Comparative Law. Journal of Legal Education, 3, 388-402.

de Francisci, P. (1921). La scienza del diritto comparato. Rivista internazionale di filosofia del diritto, 1, 233.

Dewey, J. (2004 [1916]). Democracy and Education. New York: Dover Publications.

Dworkin, R. (1991). Pragmatism, Right Answers and True Banality. In M. Brint and W. Weaver (Eds.), Pragmatism in Law and Society (pp. 359-388). Boulder, CO: Westview Press.

Fish, S. (2014). Versions of Academic Freedom. Chicago: University of Chicago Press.

Frankenberg, G. (2016). Comparative Law as Critique. Cheltenham: Edward Elgar.

Frow, J. (1988). Discipline and Discipleship. Textual Practice, 2, 307-324.

Furedi, F. (2009). Wasted. Why Education Isn't Educating. New York: Continuum.

Garrison, J. and Neiman, A. (2003). Pragmatism and Education. In N. Blake et al. (Eds.), The Blackwell Guide to the Philosophy of Education (pp. 21-38). Oxford: Blackwell.

Glanert, S. (2012). Method? In P.G. Monateri (Ed.), Methods of Comparative Law. Cheltenham: Edward Elgar.

Graveson, R.H. (1950). The Teaching of Comparative Law in the U.S.A. Journal of Comparative Legislation and International Law, 32(3/4), 31-36.

Gutteridge, H.C. (1949). Comparative Law (2nd ed.). Cambridge: Cambridge University Press.

Harding, A. and Cueto-Rua, J. (1955), Teaching Comparative Commercial Law. The American Journal of Comparative Law, 4(3), 401-403.

Harvey, M. (2002). What's So Special about Legal Translation? Meta: Journal des Traducteurs / Meta: Translators' Journal, 47(2), 177-185.

Hazard, J. (1971). Ten Years of International Teaching of Comparative Law: The Strasbourg Experiment. The American Journal of Comparative Law, 19(2), 253-263.

Husa, J. (2009). Turning the Curriculum Upside Down: Comparative Law as an Educational Tool for Constructing Pluralistic Legal Mind. German Law Journal, 10, 913-926.

Ireland-Piper, D. (2019). Teaching Public Law in a Comparative Paradigm: Virtues and Vices. The Law Teacher, 53(1), 102-118.

Kennedy, D. (2003). The Methods and the Politics. In P. Legrand and R. Munday (Eds.), Comparative Legal Studies: Traditions and Transitions (pp. 345-434). Cambridge: Cambridge University Press.

Kennedy, D. (2012). Political Ideology and Comparative Law. In M. Bussani and U. Mattei (Eds.), The Cambridge Companion to Comparative Law (pp. 35-56). Cambridge: Cambridge University Press. 
Landau, D. (2018). Legal Pragmatism and Comparative Constitutional Law. In G. Jacobsohn and M. Schor (Eds.), Comparative Constitutional Theory (pp. 208-228). Cheltenham: Edward Elgar.

Legrand, P. (2009). La comparaison des droits expliquée à mes étudiants. In P. Legrand (Ed.), Comparer les droits, résolument (pp. 209-244). Paris: Presses Universitaires de France.

Legrand, P. (2014a). Proof of Foreign Law in US Courts: A Critique of Epistemic Hubris. Journal of Comparative Law, 8, 343-388.

Legrand, P. (2014b). Law's Translation, Imperial Predilections and the Endurance of the Self. The Translator, 20(3), 290-312.

Legrand, P. (2015). Negative Comparative Law. Journal of Comparative Law, 10, 405-454.

Legrand, P. (2019). Jacques Derrida Never Wrote About Law. In P. Goodrich and M. Rosenfeld (Eds.), Administering Interpretation (pp. 105-144). New York: Fordham University Press.

Legrand, P. and Munday, R. (2003). Comparative Legal Studies: Traditions and Transitions. Cambridge: Cambridge University Press.

Mayda, J. (1959). Teaching Introduction to Law by the Comparative Method. Journal of Legal Education, 12, 585-591.

Mercescu, A. (2018). Pour une comparaison des droits indisciplinée. Basel: Helbing Lichtenhahn.

Mercescu, A. (2019a). Change of Mind, Change of Style: Lawyers' Writing Manners. International Journal of Law in Context, 15(3), 310-326.

Mercescu, A. (2019b). What Kind of Critique for Central and Eastern European Legal Studies? Comparison as One of the Answers. Folia Iuridica, 89, 45-61.

Mouffe, C. (Ed.). (1996). Deconstruction and Pragmatism. London: Routledge.

Mouffe, C. (2005). On the Political. London: Routledge.

Mueller, G. (1958). The Teaching of Comparative Law in the Course on Criminal Law. Journal of Legal Education, 11, 59-71.

Muir Watt, H. (2009). Comparer l'efficience des droits? In P. Legrand (Ed.), Comparer les droits, résolument. Paris: P.U.F.

Nicholson, C. (2013). Education and the Pragmatic Temperament. In A. Malachowski (Ed.), The Cambridge Companion to Pragmatism (pp. 249-272). Cambridge: Cambridge University Press.

O'Connor, S. (2003). [Speech at Southern Center for International Studies, Atlanta, Georgia], available at www.southerncenter.org/OConnor_transcript.pdf, p. 3.

Posner, R. (1990). What Has Pragmatism to Offer Law? Southern California Law Review, 63, 1653-1670.

Radhakrishnan, R. (2008). Is Freedom Academic? Works and Days, 26, 501-518.

Reboul, O. (2010). La philosophie de l'éducation. Paris: P.U.F. Paris.

Remak, H.H. (1971). Comparative Literature, Its Definition and Function. In N. Stallknecht and H. Frenz (Eds.), Comparative Literature, Method and Perspective. Carbondale: Southern Illinois University Press.

Rosenfeld, M. (1998). Pragmatism, Pluralism and Legal Interpretation: Posner's and Rorty's Justice without Metaphysics Meets Hate Speech. In M. Dickstein (Ed.), The Revival of Pragmatism (pp. 324-343). Durham, NC: Duke University Press.

Schlag, P. (1998). The Enchantment of Reason. Durham, NC: Duke University Press.

Schlesinger, R.B. (1954). Teaching Comparative Law: The Reaction of the Customer. The American Journal of Comparative Law, 3(4), 492-501.

Schlesinger, R.B. (1968). Formation of Contracts: A Study of the Common Core of Legal Systems, vol I. Oceana: New York. 
Seidman, R. and Thome, J. (1968). The Foreign Law Programs: The Wisconsin Idea in a World Context. Wisconsin Law Review, (2), 362-368.

Sereni, A. (1951) On Teaching Comparative Law. Harvard Law Review, 64(5), 770-779.

Taekema, S. (2006). Beyond Common Sense: Philosophical Pragmatism' Relevance to Law. Retfaerd: Nordisk Juridisk Tidsskrift, 29(4), 22-36.

Tamanaha, B. (1997). Realistic Socio-Legal Theory: Pragmatism and a Social Theory of Law. Oxford: Clarendon Press.

Thomson, A. (1987). Critical Legal Education in Britain. Journal of Law and Society, 14(1), 183-197.

Varga, C. (Ed.). (2020a). Comparative Law and Multicultural Legal Classes: Challenge or Opportunity? Cham: Springer.

Varga, C. (2020b). Comparative Law and Multicultural Legal Classes: Challenge or Opportunity? In C. Varga (Ed.), Comparative Law and Multicultural Legal Classes: Challenge or Opportunity? (pp. 3-42). Cham: Springer.

Watzlawick, P. (1984). Epilogue. In P. Watzlawick (Ed.), The Invented Reality (pp. 325-337). New York: W.W. Norton.

Waxman, M. P. (2001). Teaching Comparative Law in the 21st Century: Beyond the Civil/ Common Law Dichotomy. Journal of Legal Education, 51(2), 305-312.

Winterton, G. (1975). Comparative Law Teaching. American Journal of Comparative Law, 23, 69-70.

Wirtz, W. (1954). 'The Significant' and Legal Education. The Journal of Higher Education, 25(5), 255-258.

Zweigert, K. and Kötz, H. (1998). Introduction to Comparative Law (3rd edn., trad. Tony Weir). Oxford: OUP. 